\title{
How Temperature Affects Wastewater Nitrate Removal in a Bioelectrochemically Assisted Constructed Wetland System
}

\author{
Dan $\mathrm{Xu}^{1,2}$, Enrong Xiao ${ }^{2 *}$, Peng $\mathrm{Xu}^{2,3}$, Yin $\mathrm{Zhou}^{2,3}$, Qiaohong $\mathrm{Zhou}^{2}$, \\ Dong $\mathrm{Xu}^{2}$, Zhenbin $\mathrm{Wu}^{2}$ \\ ${ }^{1}$ College of Resources and Environmental Engineering, Wuhan University of Technology, Wuhan 430070, P.R. China \\ ${ }^{2}$ State Key Laboratory of Freshwater Ecology and Biotechnology, Institute of Hydrobiology, \\ Chinese Academy of Sciences, Wuhan 430072, P.R. China \\ ${ }^{3}$ Graduate University of Chinese Academy of Sciences, Beijing 100039, China
}

Received: 20 March 2017

Accepted: 18 July 2017

\begin{abstract}
A novel bioelectrochemically assisted constructed wetland system (BECW) was investigated using a laboratory-scale experimental apparatus for treating nitrate-contaminated water without an organic carbon source. The BECW was operated at $29 \pm 1$ and $18 \pm 1^{\circ} \mathrm{C}$, respectively, to explore the effects of temperature on the autotrophic denitrification process. The results showed that higher TN removal efficiency $(76.30 \pm 5.08 \%)$ was obtained at higher temperature when compared to a lower temperature $(48.18 \pm 4.40 \%)$. The effluent concentrations of $\mathrm{NO}_{2}^{-}-\mathrm{N}$ and $\mathrm{NH}_{4}^{+}-\mathrm{N}$ at $18 \pm 1^{\circ} \mathrm{C}$ were $0.40 \pm 0.11$ and $0.50 \pm 0.42 \mathrm{mg} \mathrm{N} \mathrm{L}^{-1}$, whereas those at $29 \pm 1^{\circ} \mathrm{C}$ could be neglected. Besides, significant accumulations of $\mathrm{NO}_{2}^{-}-\mathrm{N}^{-} \mathrm{nd} \mathrm{NH}_{4}^{+}-\mathrm{N}$ were observed in the cathode region at $18 \pm 1^{\circ} \mathrm{C}$ through quantifying different forms of nitrogen that varied along the flow path.
\end{abstract}

Keywords: constructed wetland, bioelectrochemically, nitrate removal, temperature

\section{Introduction}

Nitrate pollution of groundwater in many regions of the world has become a serious concern since its potential health threat to infants and pregnant women [1-2]. Thus many countries and organizations have set standards for the content of nitrate in drinking water. The World Health Organization (WHO) has suggested a guideline value for nitrate of $11 \mathrm{mg} \mathrm{NO}{ }_{3}^{-}-\mathrm{N} \mathrm{L}^{-1}$ in drinking water

*e-mail: erxiao@ihb.ac.cn
[3], and China's Ministry of Environmental Protection in 2006 established a strict standard of $10 \mathrm{mg} \mathrm{NO}_{3}^{-}-\mathrm{N} \mathrm{L}^{-1}$ for nitrate concentrations in drinking water (Ministry of Health, 2006). Conventional physicochemical methods, such as ion exchange [4], reverse osmosis [5], and electrodialysis [6] are not feasible for large applications due to low efficiency, generation of secondary pollutants, and mostly high cost [7]. Biological denitrification is considered to be an environmentally friendly and costcompetitive alternative for eliminating nitrates from water and wastewater [8].

Constructed wetlands (CWs) are economical, ecological, and effective engineering systems with the 
unique advantages of higher effluent quality and low operational costs [9-10]. In recent years, CWs have been widely used in the purifications of nitrate-rich water and wastewater, such as agricultural runoff, municipal wastewater treatment effluent, and polluted groundwater [11-14]. Nitrate nitrogen can be removed in CWs by the multiple functions of aquatic plants, substrates, and microorganisms. Among them, biological denitrification is generally considered to be the major nitrate removal process, particularly in those receiving high-nitrate loadings [15]. However, wastewater with low $\mathrm{C} / \mathrm{N}$ ratio, such as groundwater and secondary effluent-polluted with nitrates, mostly contain relatively low organic matter, thus leading to the requirement of additional electron donors (e.g., methanol, ethanol, and plant materials) to enhance the conventional biological denitrification process [16]. Previous studies have reported that adding external electron donors can effectively improve the denitrification process while simultaneously bringing some other problems, including secondary pollution caused by the unused carbon source and nitrite accumulation due to incomplete denitrification [17-18].

Recently, a newly bioelectrochemically assisted constructed wetland (BECW) was used to remove nitrate in wastewater with organic-free influent, and the highest nitrate removal efficiency was achieved with the applied current of $15 \mathrm{~mA}$ [19]. The BECW system was constructed by integrating a biofilm-electrode reactor with a continuous up-flow constructed wetland, in which hydrogen gas was produced by water electrolysis and denitrifying bacteria cultured on the cathode surface used hydrogen as the sole electron donor to reduce nitrate nitrogen.

Temperature, known as a key environmental factor, is related to the denitrification process by affecting the activities of the denitrifying bacteria in CWs [20]. Nitrate reduction is accomplished by autotrophic hydrogendependent denitrifying bacteria in BECWs, which is rather different from conventional constructed wetlands. The aim of this study was: 1) to investigate the effect of temperatures $\left(29 \pm 1\right.$ and $\left.18 \pm 1^{\circ} \mathrm{C}\right)$ on the denitrification performance of the $\mathrm{BECW}$ system and 2) to quantify different forms of nitrogen varied along the flow path for clarifying the nitrogen removal mechanism in this integrated system. Investigating the effect of temperature on the autotrophic denitrification process in the BECW reactor is necessary and will facilitate optimizing the integrated system.

\section{Experimental}

\section{Configuration and Setup of the BECWs}

The BECW system with a holding bucket $25 \mathrm{~L}$ (700 $\mathrm{mm}$ height, $160 \mathrm{~mm}$ in diameter) was established and shown in Fig. 1. The configuration and experimental setup of the BECWs have been described by Xu et al. [19]. Briefly, there were five layers from the bottom upward:

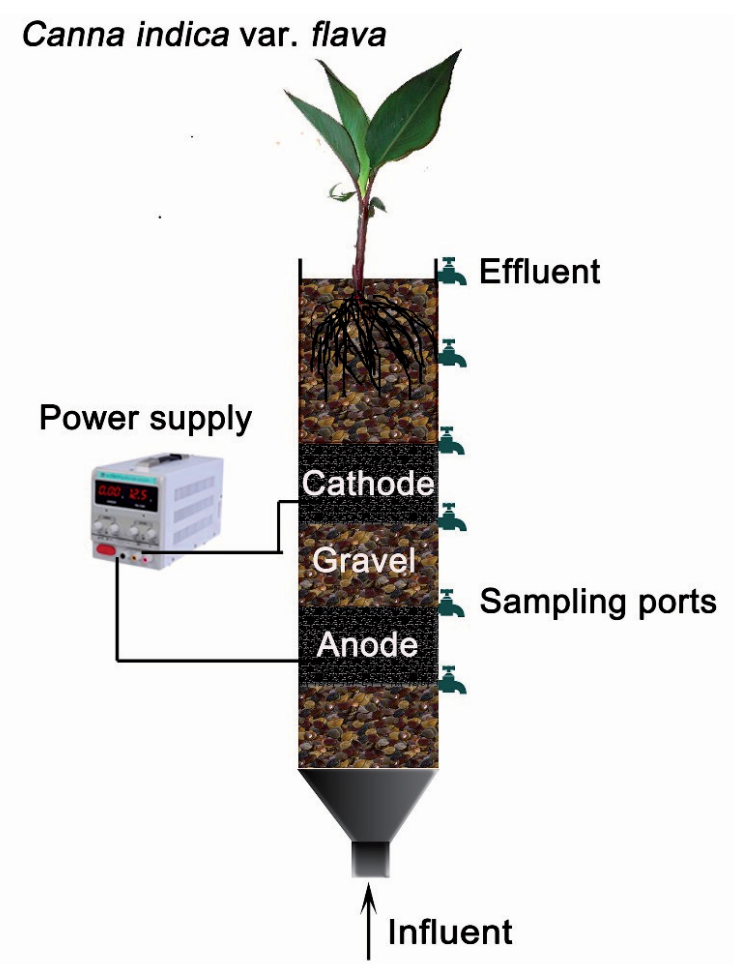

Fig. 1. Schematic representation of the BECWs used in this study.

bottom gravel layer, the anode compartment, the middle gravel layer, the cathode compartment, and then following the upper gravel layer planted with Canna indica var. flava. The upper gravel layer was $200 \mathrm{~mm}$ height while the other four layers were $100 \mathrm{~mm}$ high. The anode and cathode chamber were filled with granule active carbon (GAC, diameter 3-5 mm), and graphite felts $(300 \mathrm{~mm}$ length $\times 100 \mathrm{~mm}$ wide $\times 6 \mathrm{~mm}$ thick) were inserted into the randomly packed GAC to collect or release electrons. All graphite components were pre-treated by washing in $1 \mathrm{~N} \mathrm{HCl}$ and $1 \mathrm{~N} \mathrm{NaOH}$ [21].

In addition, a constant current of $15 \mathrm{~mA}$ was applied to the circuit by connecting the positive pole of a DC power supply (LongWei PS-305DM, Shenzhen, China) to the anode, and the negative pole to the cathode.

\section{Experimental Operation and Sample Analysis}

The inoculation process and inflow water quality of reactors were described by Xu et al. [19]. Synthetic wastewater was augmented with sodium nitrate to a target concentration of $30 \mathrm{mg} \mathrm{NO}_{3}^{-}-\mathrm{N} \mathrm{L}^{-1}$ without supplemental organic carbon. The BECWs were operated in a continuous up-flow mode with a flow rate of $1.493 \mathrm{ml} \mathrm{min}^{-1}$ (giving an HRT of $2 \mathrm{~d}$ ). To determine the influence of temperature on denitrification behavior, the experimental study was divided into two different periods: Period 1 with an average temperature of $29 \pm 1^{\circ} \mathrm{C}$ for 23 days and period 2 with an average temperature of $18 \pm 1^{\circ} \mathrm{C}$ for 17 days.

Water samples were collected from the BECW effluents and sampling ports arranged at intervals of 
$100 \mathrm{~mm}$ throughout the height of the reactors. TN, $\mathrm{NH}_{4}^{+}-\mathrm{N}, \mathrm{NO}_{2}^{-}-\mathrm{N}$, and $\mathrm{NO}_{3}^{-}-\mathrm{N}$ were analyzed according to the Standard Methods for the Examination of Water and Wastewater (APHA, 1998). Prior to analysis, except for $\mathrm{TN}$, the samples were centrifuged at 5,000 rpm for $10 \mathrm{~min}$ to spin down any suspended solids from the liquid phase. The $\mathrm{pH}$ and dissolved oxygen (DO) values were immediately measured using a portable Orion Star meter (520M-01A, Thermo, USA) equipped with a pH electrode (8107UWMMD, Thermo, USA) and a DO electrode (086030MD, Thermo, USA).

\section{Results and Discussion}

\section{$\mathrm{pH}$ and DO Profiles along the BECW System}

The distributions of $\mathrm{pH}$ and $\mathrm{DO}$ along the $\mathrm{BECW}$ reactors at two different temperatures $\left(29 \pm 1\right.$ and $\left.18 \pm 1^{\circ} \mathrm{C}\right)$ are shown in Figs 2(a-b), respectively. Both of the $\mathrm{pH}$ values along the $\mathrm{BECW}$ reactors at $29 \pm 1$ and $18 \pm 1^{\circ} \mathrm{C}$ decreased gradually with the increased reactor height until they reached $20 \mathrm{~cm}$ due to the generation of $\mathrm{H}^{+}$ during water electrolysis in the anode region, and then
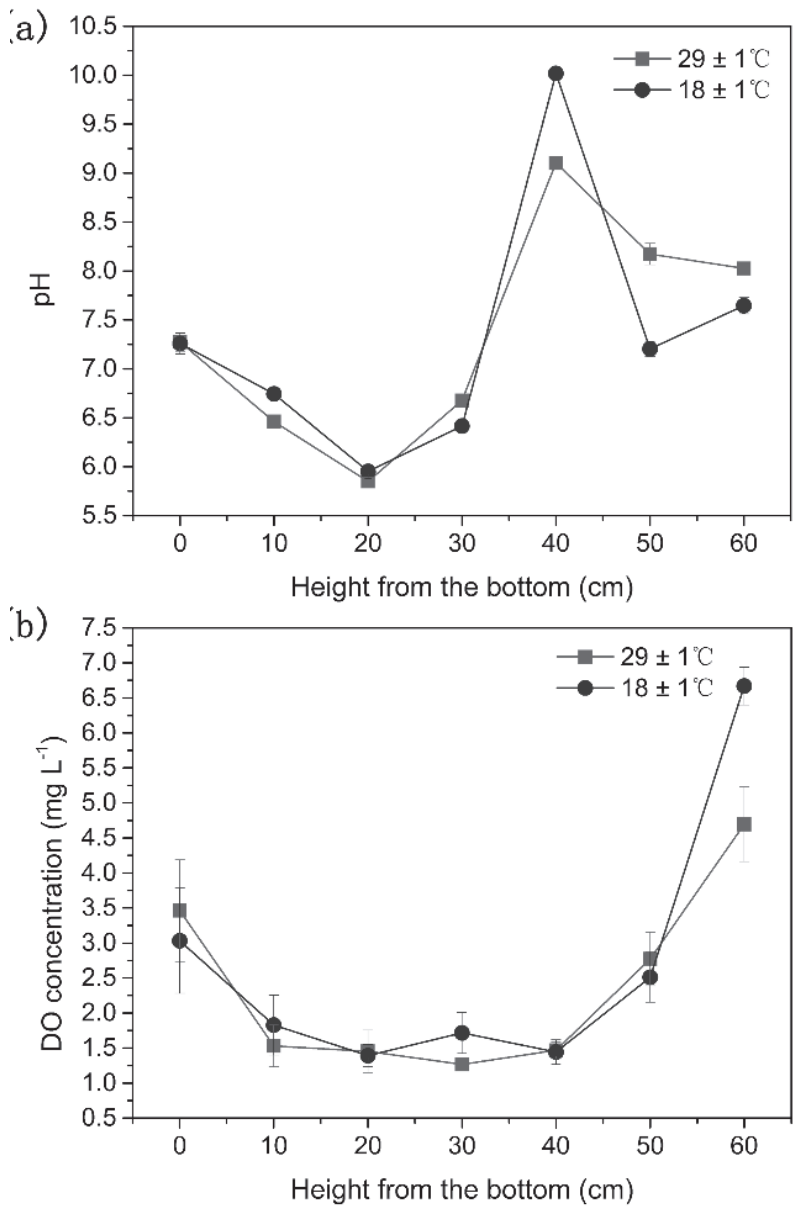

Fig. 2. $\mathrm{pH}$ a) and $\mathrm{DO}$ b) concentrations varied along the flow path in the BECWs. they increased gradually to the maximal $\mathrm{pH}$ values at a height of $40 \mathrm{~cm}$ because of the generation of $\mathrm{OH}^{-}$during the denitrification process and water electrolysis in the cathode region. The lowest $\mathrm{pH}$ values were in the anode region with $5.85 \pm 0.04$ at $29 \pm 1^{\circ} \mathrm{C}$ and $5.95 \pm 0.05$ at $18 \pm 1^{\circ} \mathrm{C}$, whereas the highest $\mathrm{pH}$ values were in the cathode region with $9.10 \pm 0.06$ at $29 \pm 1^{\circ} \mathrm{C}$ and $10.02 \pm 0.02$ at $18 \pm 1^{\circ} \mathrm{C}$. Furthermore, the $\mathrm{pH}$ value of the BECW at $29 \pm 1^{\circ} \mathrm{C}$ decreased again after leaving the cathode region to the outlet, whereas the $\mathrm{pH}$ value of the $\mathrm{BECW}$ at $18 \pm 1^{\circ} \mathrm{C}$ decreased first but increased a little. The effluent $\mathrm{pH}$ were $8.03 \pm 0.06$ at $29 \pm 1^{\circ} \mathrm{C}$ and $7.65 \pm 0.08$ at $18 \pm 1^{\circ} \mathrm{C}$. The decrease of $\mathrm{pH}$ values after leaving the cathode region were due to that root secretion and putrefaction of dead plants mitigating some alkalinity [11].

Dissolved oxygen (DO) is the measure of the oxidizing (aerobic) and reducing (anaerobic) condition of the aquatic environment. As shown in Fig. 2b, with the increasing reactor height, the DO concentrations along the reactors at $29 \pm 1$ and $18 \pm 1^{\circ} \mathrm{C}$ showed a similar trend that first decreased due to the consumption of $\mathrm{O}_{2}$ and then increased because of atmospheric reoxygenation and the root release of oxygen. Moreover, the DO concentration of the reactor effluent at $18 \pm 1^{\circ} \mathrm{C}(6.67 \pm 0.27)$ was higher than that at $29 \pm 1^{\circ} \mathrm{C}(4.70 \pm 0.53)$ due to the fact that DO concentration increased with the decrease of temperature.

\section{Nitrogen Removal Performance of the BECW System}

As illustrated in Table 1, the effluent concentrations of $\mathrm{TN}$ in the $\mathrm{BECW}$ reactors were about $7.14 \pm 1.53 \mathrm{mg}$ $\mathrm{N} \mathrm{L}^{-1}$ at $29 \pm 1^{\circ} \mathrm{C}$ and $16.49 \pm 1.40 \mathrm{mg} \mathrm{N} \mathrm{L}^{-1}$ at $18 \pm 1^{\circ} \mathrm{C}$, whereas $76.30 \pm 5.08 \%$ and $48.18 \pm 4.40 \%$ TN removal efficiencies were accomplished at $29 \pm 1$ and $18 \pm 1^{\circ} \mathrm{C}$, respectively. Moreover, we observed that nitrate removal efficiencies at higher temperatures were also much higher than those at lower temperatures. It is known that microbial denitrification processes are strongly linked to temperature. In general, higher temperatures lead to higher biological activity and growth rates, whereas lower temperatures will hinder biological activity [2225]. Sirivedhin and Gray found that the overall nitrate removal rate was significantly higher in summer than in winter [23]. Beutel et al. also observed a significant positive correlation between the nitrate loss rates and water temperature [24]. It is also noticed that the effluent concentrations of $\mathrm{NO}_{2}^{-}-\mathrm{N}$ and $\mathrm{NH}_{4}^{+}-\mathrm{N}$ at $29 \pm 1^{\circ} \mathrm{C}$ was a bit higher than those at $18 \pm 1^{\circ} \mathrm{C}$.

In order to ascertain the reason for the difference of $\mathrm{N}$ removal efficiencies between the BECWs with two temperatures, the concentrations of various forms of nitrogen varied along the reactor height were investigated (see Fig. 3). When the BECW reactor was operated at $29 \pm 1^{\circ} \mathrm{C}$, the concentration of TN declined gradually from $30.13 \pm 0.31$ to $27.69 \pm 2.19 \mathrm{mg} \mathrm{N} \mathrm{L}^{-1}$ until they reached the reactor height of $20 \mathrm{~cm}$, and then decreased drastically to $5.93 \pm 0.14 \mathrm{mg} \mathrm{N} \mathrm{L}^{-1}$ from the reactor height of 20 to $40 \mathrm{~cm}$, yet it increased to $7.45 \pm 1.05 \mathrm{mg} \mathrm{N} \mathrm{L}^{-1}$ at the 
Table 1. Effluent $\mathrm{N}$ characteristics in the BECWs.

\begin{tabular}{|c|c|c|c|c|c|c|}
\hline \multirow{2}{*}{$\begin{array}{c}\text { Temperature } \\
\left({ }^{\circ} \mathrm{C}\right)\end{array}$} & \multicolumn{3}{|c|}{ Effluent $\mathrm{N}$ concentration $\left(\mathrm{mg} \mathrm{N} \mathrm{L}^{-1}\right)$} & \multicolumn{2}{c|}{$\mathrm{N}$ removal efficiency (\%) } \\
\cline { 2 - 7 } & $\mathrm{TN}$ & $\mathrm{NO}_{3}-\mathrm{N}$ & $\mathrm{NO}_{2}^{-}-\mathrm{N}$ & $\mathrm{NH}_{4}^{+}-\mathrm{N}$ & $\mathrm{TN}$ & $\mathrm{NO}_{3}^{-}-\mathrm{N}^{-1}$ \\
\hline $29 \pm 1{ }^{\circ} \mathrm{C}$ & $7.14 \pm 1.53$ & $6.12 \pm 0.80$ & $0.01 \pm 0.01$ & not detected & $76.30 \pm 5.08$ & $78.92 \pm 3.12$ \\
\hline $18 \pm 1^{\circ} \mathrm{C}$ & $16.49 \pm 1.40$ & $14.09 \pm 0.99$ & $0.40 \pm 0.11$ & $0.50 \pm 0.42$ & $48.18 \pm 4.40$ & $55.73 \pm 3.08$ \\
\hline
\end{tabular}

height of $50 \mathrm{~cm}$, finally decreasing to $7.14 \pm 1.53 \mathrm{mg} \mathrm{N} \mathrm{L}^{-1}$ (Fig. 3a). When constructing the reactor, the height from 30 to $40 \mathrm{~cm}$ was designed as the cathode region. However, the actual cathode region was lower by a few centimeters than the height of $30-40 \mathrm{~cm}$ owing to the matrix infiltration after a period of operation. Thus, cathodic autotrophic denitrification was considered to be the main reason for the drastic decrease of TN concentration from the height of 30 to $40 \mathrm{~cm}$. The change curve of TN concentration at $18 \pm 1^{\circ} \mathrm{C}$ was consistent with that at $29 \pm 1^{\circ} \mathrm{C}$. But the $\mathrm{TN}$ concentration varying along the reactor height at lower temperatures was distinctly higher compared to that at higher ones. It is known that lower temperatures will lead to lower denitrification efficiency in the cathode region, but the reason for the increase of $\mathrm{TN}$ concentration in the rhizosphere region is unknown, which needs further research. As shown in Figs 3(c-d), the concentrations of nitrite and ammonia were negligible along the reactor at $29 \pm 1^{\circ} \mathrm{C}$. Thus the change trend of $\mathrm{NO}_{3}^{-}-\mathrm{N}$ concentration was quite similar with that of TN concentration owing to the fact that the TN was mainly composed of nitrate. However, the nitrogen forms of the $\mathrm{BECW}$ along reactor height opera-ting at $18 \pm 1^{\circ} \mathrm{C}$ was rather different. The effluent concentration of $\mathrm{NO}_{3}^{-}-\mathrm{N}$ at the height of $40 \mathrm{~cm}$ decreased to $2.83 \pm 0.62 \mathrm{mg} \mathrm{N} \mathrm{L}^{-1}$ at $18 \pm 1^{\circ} \mathrm{C}$, which was lower than that at $29 \pm 1^{\circ} \mathrm{C}\left(4.86 \pm 0.63 \mathrm{mg} \mathrm{N} \mathrm{L}^{-1}\right)$. Moreover, both of the maximum concentrations of nitrite and ammonia occurred at a height of $40 \mathrm{~cm}$, with the corresponding concentrations of $4.98 \pm 0.80$ and $4.37 \pm 0.26 \mathrm{mg} \mathrm{N} \mathrm{L}^{-1}$, respectively. Zhou et al. demonstrated that the suitable temperature range of performing a $\mathrm{BER}$ was $30-35^{\circ} \mathrm{C}$, and a temperature lower than $25^{\circ} \mathrm{C}$ or higher than $40^{\circ} \mathrm{C}$ would lead to a significant accumulation of nitrite [26]. In this study, temperature also played an important role for nitrite evolution, and the low temperature was responsible
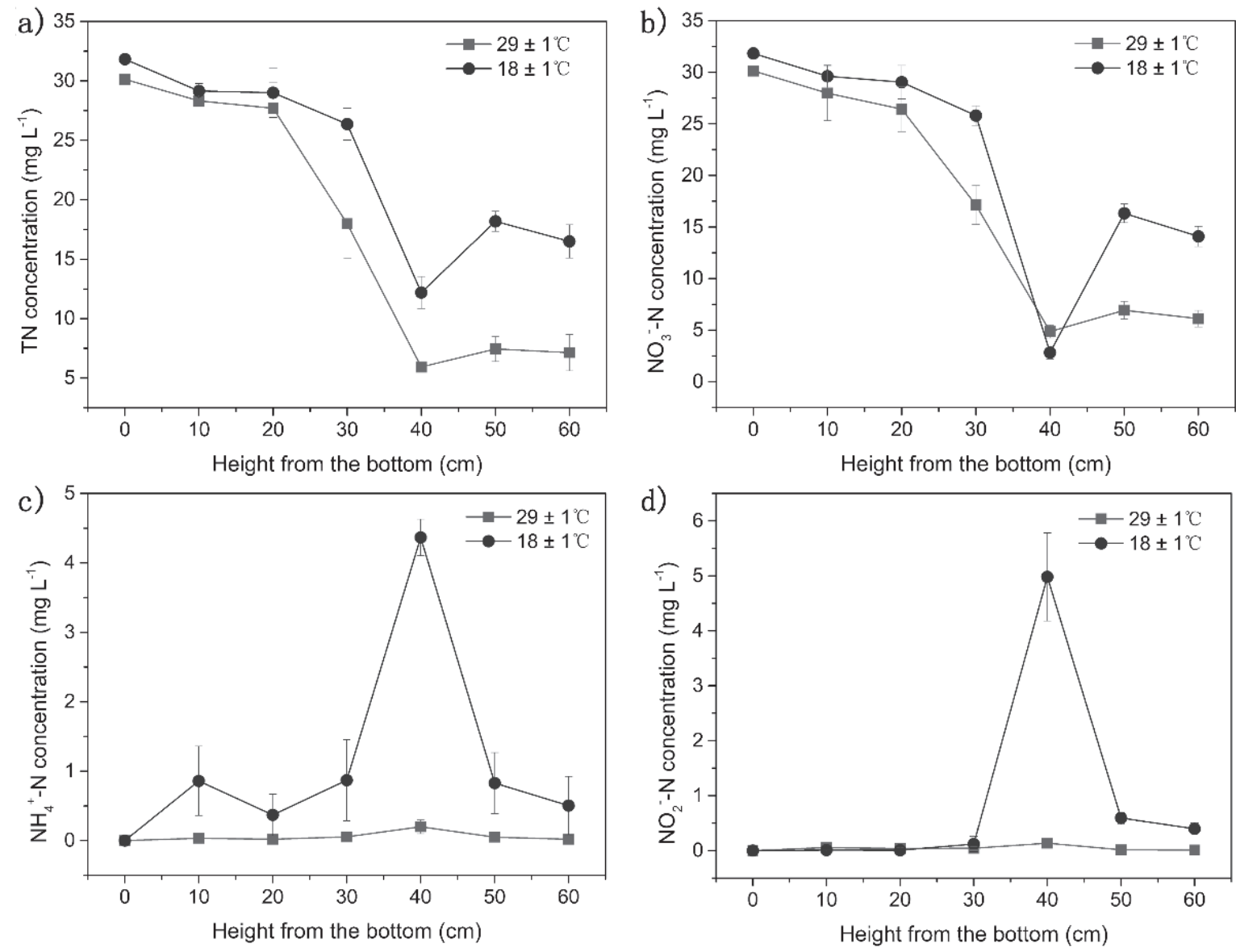

Fig. 3. $\mathrm{TN}$ a), $\mathrm{NO}_{3}^{-}-\mathrm{N} \mathrm{b}$ ), $\mathrm{NH}_{4}^{+}-\mathrm{N} \mathrm{c}$ ), and $\mathrm{NO}_{2}^{-}-\mathrm{N}$ d) concentrations varied along the flow path in the BECWs. 
for the accumulation of nitrite in the cathode region of $\mathrm{BECW}$ at $18 \pm 1^{\circ} \mathrm{C}$. Previous studies have reported dissimilatory nitrate reduction in constructed wetlands [27-28]. Owing to the requirement for more electrons, dissimilatory nitrate reduction, which includes the reduction of $\mathrm{NO}_{2}^{-}-\mathrm{N}$ and $\mathrm{NO}_{3}^{-}-\mathrm{N}$ to $\mathrm{NH}_{4}^{+}-\mathrm{N}$, is considered favored by carbon-rich and nitrate-limited conditions [29]. In this study, the specific conditions of the BECW system at a lower temperature may promote the growth of nitrate-ammonifying bacteria and limit the activity of nitrite-reducing bacteria for such an unconventional transformation. Besides, although the concentrations of nitrite and ammonia decreased at the rhizosphere region because of reoxygenation and the root release of oxygen [30], the effluent concentrations were still higher than those at $29 \pm 1^{\circ} \mathrm{C}$. According to the obtained results, low temperatures would limit nitrate removal of BECW through decreasing its autotrophic denitrification efficiency in the cathode region, thus measurements should be taken to improve denitrification efficiency of $\mathrm{BECW}$ in future studies. In order to improve the nitrate removal efficiency at a relatively low temperature, increasing the current density and HRT or combining with heterotrophic denitrification can be considered. In BERs, electrical current plays a key role in providing suitable hydrogen concentration for hydrogenotrophic bacteria and achieving a high rate of denitrification [31]. Previous studies showed that the quantity of electron donors (hydrogen concentration) are completely dependent on current density and HRT, and higher current density and longer HRT in a certain range could lead to a higher denitrification rate, thus decreasing the nitrate and nitrite concentrations of the effluent $[19,26,32]$. Besides, the coexistence of autotrophic and heterotrophic denitrification processes prevailing in BESs can improve denitrification efficiency, reduce the consumption of electrical energy, and buffer the $\mathrm{pH}$ [33-35]. Thus, adding a small amount of organic carbon source could also be a possible solution to enhancing the denitrification efficiency of BECW at low temperatures.

\section{Conclusions}

In this study, the effect of temperature on the autotrophic denitrification process in a novel bioelectrochemically assisted constructed wetland system (BECW) with organic-free influent was investigated. The results indicated that higher TN removal efficiency $(76.30 \pm 5.08 \%)$ was obtained at higher temperatures when compared to that at lower temperatures $(48.18 \pm 4.40 \%)$. The BECW system operating at a lower temperature may lead to significant accumulations of $\mathrm{NO}_{2}^{-}-\mathrm{N}$ and $\mathrm{NH}_{4}^{+}-\mathrm{N}$ in the cathode region and higher effluent concentrations of them. Thus, measures taken to improve the denitrification efficiency of the BECW system at a relatively low temperature will be the focus of future research.

\section{Acknowledgements}

This research was supported financially by the National Natural Science Foundation of China (51308530), the Provincial Natural Science Foundation of Hubei Province (2015CFB558), the National Key Research and Development Plan of China (2016YFC0500403-03), and the Key Research Program of the Chinese Academy of Sciences (KFZD-SW-302-02).

\section{References}

1. SPADLDING R.F., EXNER M.E. Occurrence of nitrate in groundwater - a review. Journal of Environmental Quality. 22 (3), 392, 1993.

2. ZHANG X.N., GUO Q.P., SHEN X.X., YU S.W., QIU G.Y. Water quality, agriculture and food safety in China: Current situation, trends, interdependencies, and management. Journal of Integrative Agriculture. 14 (11), 2365, 2015.

3. ORGANIZATION W.H. Guidelines for drinking-water quality World Health Organization, Geneva, Switzerland, 2011.

4. REN Y., YE Y., ZHU J., HU K., WANG Y. Characterization and evaluation of a macroporous anion exchange resin for nitrate removal from drinking water. Desalination and Water Treatment. 57 (37), 17430, 2016.

5. EPSZTEIN R., NIR O., LAHAV O., GREEN M. Selective nitrate removal from groundwater using a hybrid nanofiltration-reverse osmosis filtration scheme. Chemical Engineering Journal. 279, 372, 2015.

6. PIRSAHEB M., KHOSRAVI T., SHARAFI K., MOURADI $M$. Comparing operational cost and performance evaluation of electrodialysis and reverse osmosis systems in nitrate removal from drinking water in Golshahr, Mashhad. Desalination and Water Treatment. 57 (12), 5391, 2016.

7. PARK J.Y., YOO Y.J. Biological nitrate removal in industrial wastewater treatment: which electron donor we can choose. Applied Microbiology and Biotechnology 82 (3), 415, 2009.

8. PETROVIČ A., SIMONIČ M. Effect of Chlorella sorokiniana on the biological denitrification of drinking water. Environmental Science and Pollution Research 22 (7), 5171, 2015.

9. TAO M., HE F., XU D., LI M., WU Z.B. How artificial aeration improved the sewage treatment of an integrated vertical-flow constructed wetland. Polish Journal of Environmental Studies 19(1), 181, 2010.

10. WU S.B., KUSCHK P., BRIX H., VYMAZAL J., DONG R.J. Development of constructed wetlands in performance intensifications for wastewater treatment: a nitrogen and organic matter targeted review. Water Research 57, 40, 2014.

11. LU S.L., HU H.Y., SUN Y.X., YANG J. Effect of carbon source on the denitrification in constructed wetlands. Journal of Environmental Sciences 21(8), 1036, 2009.

12. LU S.Y., ZHANG P.Y., JIN X.C., XIANG C.S., GUI M., ZHANG J., LI F.M. Nitrogen removal from agricultural runoff by full-scale constructed wetland in China. Hydrobiologia 621 (1), 2009.

13. ZHANG C.H., TAN S.H., LI J., PENG C. Polishing of secondary effluents by a two stage vertical flow constructed wetland. Polish Journal of Environmental Studies 2, 923, 2015. 
14. COBAN O., KUSCHK P., WELLS N.S., STRAUCH G., KNOELLER K. Microbial nitrogen transformation in constructed wetlands treating contaminated groundwater. Environmental Science and Pollution Research 22 (17), 12829, 2015.

15. ALMEIDA A., CARVALHO F., IMAGINÁRIO M.J., CASTANHEIRA I., PRAZERES A.R., RIBEIRO C. Nitrate removal in vertical flow constructed wetland planted with Vetiveria zizanioides: Effect of hydraulic load. Ecological Engineering 99, 535, 2017.

16. ZHANG C., YIN Q., WEN Y., GUO W., LIU C., ZHOU Q. Enhanced nitrate removal in self-supplying carbon source constructed wetlands treating secondary effluent: The roles of plants and plant fermentation broth. Ecological Engineering 91, 310, 2016.

17. KARANASIOS K.A., VASILIADOU I.A., TEKERLEKOPOULOU A.G., AKRATOS C.S., PAVLOU S., VAYENAS D.V. Effect of $\mathrm{C} / \mathrm{N}$ ratio and support material on heterotrophic denitrification of potable water in bio-filters using sugar as carbon source. International Biodeterioration and Biodegradation. 111, 62, 2016.

18. HANG Q., WANG H., CHU Z., YE B., LI C., HOU Z. Application of plant carbon source for denitrification by constructed wetland and bioreactor: review of recent development. Environmental Science and Pollution Research 23 (9), 8260, 2016.

19. XU D., XIAO E.R., XU P., ZHOU Y., HE F., ZHOU Q.H., XU D., WU Z.B. Performance and microbial communities of completely autotrophic denitrification in a bioelectrochemically-assisted constructed wetland system for nitrate removal. Bioresource Technology 228, 39, 2017.

20. LANGERGRABER G. Simulation of the treatment performance of outdoor subsurface flow constructed wetlands in temperate climates. Science of the Total Environment 380 (1-3), 210, 2007.

21. BOND D.R., LOVLEY D.R. Electricity Production by Geobacter sulfurreducens Attached to Electrodes. Applied and Environmental Microbiology 69 (3), 1548, 2003.

22. WANG L., LI T. Effects of seasonal temperature variation on nitrification, anammox process, and bacteria involved in a pilot-scale constructed wetland. Environmental Science and Pollution Research 22 (5), 3774, 2015.

23. SIRIVEDHIN T., GRAY K.A. Factors affecting denitrification rates in experimental wetlands: field and laboratory studies. Ecological Engineering 26 (2), 167, 2006.

24. BEUTEL M.W., NEWTON C.D., BROUILLARD E.S., WATTS R.J. Nitrate removal in surface-flow constructed wetlands treating dilute agricultural runoff in the lower Yakima Basin, Washington. Ecological Engineering 35 (10), 1538, 2009.

25. MIETTO A, POLITEO M, BRESCHIGLIARO S, BORIN $M$. Temperature influence on nitrogen removal in a hybrid constructed wetland system in Northern Italy. Ecological Engineering 75, 291, 2015.

26. ZHOU M., FU W., GU H., LEI L. Nitrate removal from groundwater by a novel three-dimensional electrode biofilm reactor. Electrochimica Acta 52 (19), 6052, 2007.

27. VYMAZAL J., KRÖPFELOVÁ L. A three-stage experimental constructed wetland for treatment of domestic sewage: first 2 years of operation. Ecological Engineering 37 (1), 90, 2011.

28. MATHESON F.E., SUKIAS J.P. Nitrate removal processes in a constructed wetland treating drainage from dairy pasture. Ecological Engineering 36 (10), 1260, 2010.

29. HARDISON A.K., ALGAR C.K., GIBLIN A.E., RICH J.J. Influence of organic carbon and nitrate loading on partitioning between dissimilatory nitrate reduction to ammonium (DNRA) and $\mathrm{N}_{2}$ production. Geochimica et Cosmochimica Acta 164, 146, 2015.

30. LIU H.Q., HU Z., ZHANG J., NGO H.H., GUO W.S., LIANG S., FAN J.L., LU S.Y., WU H.M. Optimizations on supply and distribution of dissolved oxygen in constructed wetlands: A review. Bioresource Technology 214, 797, 2016.

31. MOUSAVI S., IBRAHIM S., AROUA M.K., GHAFARI S. Development of nitrate elimination by autohydrogenotrophic bacteria in bio-electrochemical reactors - A review. Biochemical Engineering Journal 67, 251, 2012.

32. HUANG B., FENG H., DING Y., ZHENG X., WANG M., LI N., SHEN D., ZHANG H. Microbial metabolism and activity in terms of nitrate removal in bioelectrochemical systems. Electrochimica Acta 113, 29, 2013.

33. TONG S., ZHANG B., FENG C., ZHAO Y., CHEN N., HAO C., FU J., ZHAO L. Characteristics of heterotrophic/ biofilm-electrode autotrophic denitrification for nitrate removal from groundwater. Bioresource Technology 148, 121, 2013.

34. HUANG B., FENG H., WANG M., LI N., CONG Y., SHEN D. How to ascertain the importance of autotrophic denitrification process in a bioelectrochemical system. Bioresource Technology 146, 525, 2013.

35. LEE D.U., LEE I.S., CHOI Y.D., BAE J.H. Effects of external carbon source and empty bed contact time on simultaneous heterotrophic and sulfur-utilizing autotrophic denitrification. Process Biochemistry 36 (12), 1215, 2001. 